\title{
Drought Status in Kano State
}

\author{
IBRAHIM MUKHTAR \\ Ministry of Agriculture and \\ Natural Resources
}

The Diought within the last two to there years has only brought into focus a trend that Kano State has been experiencing for quite some time with regard to livestock husbandry. As population and industrialization increased and as more and more land was grabbed for arable farming and for industrial use, the livestock owner (Fulani) was pushed and compressed to the poorer and destitute lands in the State. And in recent years, even the poorer land is becoming increasingly difficult to be used by Livestock herdsmen because of the introduction of irrigation agriculture. The price of the destitute land itself has increased unbelievably because of the increase demand. Cattle Ranching such as the Fulani know it, is therefore being priced out of Kano Land.

$\begin{array}{lr}\text { Acreage of Kano State } & \\ \text { Farm Crops } & 6,740,658 \\ \begin{array}{l}\text { Non-Agricultural Lands } \\ \text { (River, Houses, etc.) }\end{array} \\ \begin{array}{lr}\text { Forest Reserve } & 53,000 \\ \text { Unreserved Forest and Bush } & 537,975 \\ \text { Waste land (Sandunes nut } & 354,727 \\ \text { etc) } & 2,665,000 \\ \text { Total } & \overline{10,351,360}\end{array}\end{array}$

We agree with the Federal Livestock Department estimate that for the estimated 500,000 cattle in the State to survive, we need 3,000,000 acres of developed pasture lands. From the table it will appear as simple that the waste lands and the bush can easily provide the needed $3,000,000$ acres. But it is not really so easy. It costs N10 per acre to develop virgin land in Kano. So that at least $\mathrm{N} 30,000,000$ will be required to only develop the waste land. In most cases compensation may be paid for the lands as farmers may have claimed title to them even though they may not be using them. To compensate $3,000,000$ acres will require $\$ 360,000,000$ at the rate of $\$ 120$, per acre. Besides, there are the problems of demarcation surveying, staff, and most importantly gazetting which is almost impossible because of the endless red tape involved. While all this is being done it must be kept in mind that irrigation and industry are buying up land as well. They will not wait until we finished. So far we hold title to only 9939 acres of ungazetted but demarcated and developed pasture lands (and even these are constantly being encroached upon) and working at the maximum possible rate of 5,000 acres per year, (taking into consideration money and staff), you can see that by 1980 we may only hold title to no more than 40,000 acres of developed pasture land.

This lack of safe grazing has therefore forced the Fulani man to move from the state causing a steady decline in the cattle population. Kano is already having difficulty keeping its 500,000 or so cattle. 
Cattle Population Kano State

\begin{tabular}{lll}
$1968 / 69$ & $=$ & 526,138 \\
\hline $1969 / 70$ & $=$ & 490,689 \\
\hline $1970 / 71$ & $=$ & 490,954 \\
\hline $1971 / 72$ & 498,954 \\
\hline $1972 / 73$ & $=$ & 458,579
\end{tabular}

Still, Kano has designed several piograms within its capability to ensure that the loss of the cattle is minimized and the Government Stock is also steadily being increased. Our ultimate aim is to increase output per animal through intensive management and breeding to make up for the loss in numbers. Such programs include the following:

\section{Supplementary Feeding and Fodder Conser- vation}

A concentrate mixture of $74 \%$ cotton seed, $25 \%$ cake (groundnut or cotton seed) and $1 \%$ salt, the supplementary feed is distributed to livestock owners in all the administrative areas of the State at nearly $85 \%$ subsidy. It is always available at most of the dry season grazing areas. It contains $25 \%$ D.P. and $90 \%$ T.D.N. This year alone 5,000 tons of the stuff were distributed to save the livestock.

Through extension we are teaching some livestock owners to conserve fodder in trench silos and to bale grass for dry season feeding. By this method we feel that at least 200,000 cattle can be saved using crop residues from farming operations in the State.

Crop Residues available in the State

\begin{tabular}{|l|r|r|r|r|}
\hline \multicolumn{1}{|c|}{ Name of Crop } & $\begin{array}{r}\text { Total Production } \\
\text { (tons) }\end{array}$ & $\begin{array}{r}\text { Estimated roughage } \\
\text { (tons) }\end{array}$ & $\begin{array}{c}\text { No. of cattle } \\
\text { supported }\end{array}$ & \multicolumn{1}{c|}{ Remark } \\
\hline 993,000 & $1,866,000$ & Almost Nil & It is used for roof- \\
\hline Guinea corn & 681,000 & $1,702,500$ &,$\quad$, & ing and fuel \\
\hline Millet & 42,000 & 42,000 &,$\quad$, & $\begin{array}{l}\text { Mostly goes to was. } \\
\text { te and fuel }\end{array}$ \\
\hline Maize & 4,000 & 10,000 & 3,360 & $10 \%$ Waste \\
\hline Wheat & 2,000 & 5,000 & 1,700 & $10 \%$, \\
\hline Rice & 580,000 & 667,000 & 202,944 & $20 \%$, \\
\hline G/Nut & 29,000 & 13,050 & 5,400 & $10 \%$, \\
\hline Beans & 2,500 & 1,375 & 5,000 & Bulls , \\
\hline Cotton & $2,273,000$ & $4,306,925$ & 218,404 & \\
\hline Total & & & \\
\hline
\end{tabular}

Artificial Insemination. At present A.I. is carried out in the Metropolitan Kano Area as a trial and it is also carried out in the Livestock Centres. The whole aim is to get larger animals of greater feed efficiency and production of meat and milk.

Livestock Investigation Centres and Cattle Ranches. The six Livestock centres in the State are being expanded to hold more livestock. Two ranches at Bunkure 
and Sumaila are being constructed and an Intensive Animal Rehabilitation Centre is being erected near the Bagauda Lake Hotel. These will Ultimately occupy
50,000 acres of the State and by 1980 will hold nearly 11,200 cattle. These development are as follows:

\begin{tabular}{|l|c|c|}
\hline \multicolumn{1}{|c|}{ Name } & Acreage & Estimated No. Cattle by 1980 \\
\hline Sumaila & 37,000 & 3,000 \\
\hline Bunkure & 8,000 & 800 \\
\hline Kadawa & 700 & 150 \\
\hline Kano (Including Hotoro) & 400 & 800 \\
\hline Birnin Kudu & 360 & 500 \\
\hline Gumel & 1,300 & 700 \\
\hline Gaya & 200 & 250 \\
\hline Animal Rehabilitation & 1,920 & 5,000 \\
\hline Centre & 200 & - \\
\hline Dangora (Goats) & 200 & - \\
\hline Rano (Sheep) & 50,280 & 11,200 \\
\hline Total & & \\
\hline
\end{tabular}

Intensive Pasture Improvement. We aim to acquire large tracts of waste lands in the areas where they are available at minimum cost and introduce intensive pasture management using water from bore holes. Each of these lands will be about 10 miles (i.e. 64,000 acres).

Gamba grass (Andropogon gayanus) will be established; also a legume grass seed will be broadcast to form a mixed pasture capable of suppoiting one cattle per three acres. Total number of cattle for graze in one unit will be about 20,000 . If we are able to build two by 1980 , this will save another 40,000 cattle. Licensed grazing will be introduced and a fee will be fixed.
Kano River Project. Within the Kano River Irrigation Project, there are some more or less resident cattle which must be confined in order to protect the yearround croplands. The gross area of the scheme are 130,000 acres. Of this. 50,000 acres ate suitable for irrigation and 49,000 acres is suitable for rainfed cropping. The balance of 30,000 acres consisting of waste and bad lands will be developed for grazing and together with the residues from the irrigated and rainfed cropping lands a total of 35,000 head of cattle can be confined and supported in the area.

Now, let us go back and take stock. You will see that the Kano programs will support 267,304 cattle by 1980 on a total of 785,975 acres. 
Estimated Position by 1980

\begin{tabular}{|l|c|c|}
\hline \multicolumn{1}{|c|}{ Source of fodder } & Acreage & $\begin{array}{c}\text { Estimated Cattle } \\
\text { Supported }\end{array}$ \\
\hline $\begin{array}{l}\text { Pasture Improvement and } \\
\text { Supplementation }\end{array}$ & $\begin{array}{l}\text { Intensive pasture } \\
\text { improvement) } \\
\text { Improvement, 128,000 } \\
\text { Intere }\end{array}$ & 42,700 \\
\hline $\begin{array}{l}\text { Crop Residues in the } \\
\text { State }\end{array}$ & $\begin{array}{l}\text { Nil; the residues will be } \\
\text { routed to the occupied } \\
\text { pasture lands and Forest } \\
\text { Reserves. }\end{array}$ & 218,404 \\
\hline Kano River Project & 30,000 & 35,000 \\
\hline $\begin{array}{l}\text { Livestock centres and } \\
\text { ranches }\end{array}$ & 50,000 & 11,200 \\
\hline Forest Reserves & 537,975 & - \\
\hline Totals & 785,975 & 267,304 \\
\hline
\end{tabular}

So you see, much as we would try our best, it will be next to impossible to bring $3,000,000$ acres under our control. And in effect we are not in a position to really do much more for the Fulani herdsman.

Then you will ask me, but can the State afford to neglect the Fulani herdsman, thus forcing him to migrate further South? And I will say, but what else can the State do? Three hundred and ninety million Naira is required to cater for the Fulani, and that is no small money even for a State like Kano. Besides, is the Stateless Fulani really State responsibility alone? Is he not a part and parcel of the Nigerian problem? Is he not equally the responsibility of the Federal Government? What is happening in Kano, Mr. President, is really a premonition of what will happen in all the livestock-producing States in the Federation. It is only a question of when.

Yes Mr. President, the Federal Government owes the Fulani herdsman, who knows no boundaries, who considers all lands his divine inheritance, a living. And his task is everybody's problem unless Nigeria is going to become a serious importer of livestock products. Since the Federal Government has the money, now, not later, is the time for the task of the Fulani to be done. 